\title{
Impact of aluminium based hydrolyzing coagulants and aids in river water clarification
}

\author{
S. Mukherjee ${ }^{1,3}$, A. K. Bhattacharya ${ }^{2}$ \& S. N. Mondal $^{3}$ \\ ${ }^{1}$ Ramakrishna Mission Shilpapitha, Belgharia, Kolkata, India \\ ${ }^{2}$ Waterlife India Private Limited, Kolkata, India \\ ${ }^{3}$ National Institute of Technical Teachers' Training and Research, \\ Kolkata, India
}

\begin{abstract}
Coagulation and flocculation as a physicochemical treatment process has received considerable attention in recent times for clarification of raw water. Different hydrolyzing coagulants are normally employed for clarification, however among them aluminium based salts have attained significance particularly in the treatment process for preparation of drinking water. In the present case different aluminium based salts, polymers and coagulant aids were studied to evaluate their performances and compared. The study mainly focused on the optimization of turbidity, which remains the principal criterion for effectiveness of the clarification process. Along with this, different other parameters, particularly residual aluminium were studied to foresee any hazard that may creep up the clarification process.

Poly-aluminum Chloride (PACl) when used in tandem with Alum increased the efficiency of Alum whereas Bentonite Powder had no effect on it in terms of reduction of turbidity. Regarding residual aluminium, $\mathrm{PACl}$ showed a character different from the traditional salts.

Keywords: coagulation, flocculation, hydrolyzing coagulants, river water, turbidity; residual aluminium.
\end{abstract}

\section{Introduction}

The production of potable water from raw river water is hampered by the presence of organic and/or inorganic load. Generally these substances are in colloidal form i.e. the dispersed phase of the particles of small sizes (about a few 
microns). The very significant specific surface area of the particles and the existence of surface charge on these colloids explain the prevalence of surface forces over volume forces. This phenomenon stabilizes the system and removes any possibility of spontaneous settling (Gregory [1]; Franceschi et al. [2]). The addition of mineral salts or organic compounds causes agglomeration of these particles allowing their elimination by filtration or decantation (Alaert and Van Haute [3], Li and Gregory [4]).

Aluminium salts are the chemicals most commonly used for the coagulation process. However, some recent studies have discussed about the drawbacks of using alum salts, for example Alzheimer's disease and other related problems associated with residual aluminium in treated water (Pan et al. [5], Divakaran and Pillai [6], Schintu et al. [7]). To assess the severity of this problem as well as to improve the coagulation and flocculation processes for obtaining good quality treated water, different aluminium based salts and aids were examined. In most water treatment plants, the minimal coagulant concentration and the residual turbidity of the water are determined by the Jar-test technique (Dempsey [8]).

In the present study different aluminium based salts, namely, aluminium sulphate $\left(\mathrm{Al}_{2}\left(\mathrm{SO}_{4}\right)_{3}, 16 \mathrm{H}_{2} \mathrm{O}\right)$, potash alum $\left(\mathrm{KAl}\left(\mathrm{SO}_{4}\right)_{2}, 12 \mathrm{H}_{2} \mathrm{O}\right)$ with and without Bentonite Powder \& Poly-aluminium chloride $(\mathrm{PACl})$ and Poly-aluminium chloride $(\mathrm{PACl})$ independently, were used to study parameters including residual aluminium.

\section{Materials and methods}

\subsection{Sampling}

The raw river water samples were taken from the Ahiritola Ghat, in Kolkata from the river Ganga. The samples were treated with Aluminium Sulphate, Potash Alum with and without performance enhancing substances and PACl to obtain optimum dosages of coagulants and their effects on different parameters, particularly in the low and medium turbidity raw river waters.

Special precautions according to section 1060B of Standard Methods for the Examination of Water and Wastewater APHA, 1995 [9] were taken into account for sample collection, transport and preservation.

\subsection{Experimental procedures}

For each sample the following analyses were carried out

- $\quad$ Turbidity (by HACH 2100N TURBIDIMETER, USA)

- $\quad \mathrm{pH}$ (by WTW, inolab pH730, Germany)

- Total Alkalinity

- Total Dissolved Solid (TDS) (by WTW, inolab cond720, Germany)

- Residual Aluminium (by HACH, DR5000 UV-VIS Spectrophotometer)

- $\quad$ Sludge Volume (by Imhoff Cone - BOROSIL). 
The Standard Practice for Coagulation-flocculation Jar Test of Water, ASTM D 2035 [10], was first adopted in 1980 and re-approved in 1999. Since coagulant interactions are very complex, laboratory studies are needed to determine the suitable coagulant, optimal dosage, duration and intensity of mixing and flocculation. The coagulation and flocculation experiments were carried out by Jar test (by Programmable Phipps and Birds Jar Test Apparatus, Richmond, VA USA Model - PB - 900. The coagulants chosen were Aluminium Sulphate $\left(\mathrm{Al}_{2}\left(\mathrm{SO}_{4}\right)_{3}, 16 \mathrm{H}_{2} \mathrm{O}\right)$, Potash Alum $\left(\mathrm{KAl}\left(\mathrm{SO}_{4}\right)_{2}, 12 \mathrm{H}_{2} \mathrm{O}\right)$ - supplied by Merck India Limited). Bentonite Powder (Aluminium Silicate Hydrate) supplied by Merck India Limited, was used as an adsorbent aid to Potash Alum. Polyaluminium Chloride ( $\mathrm{PACl}$ ), a pre-polymerized coagulant, is increasingly used in recent years because of its advantages over simple salts. It is effective over a wide $\mathrm{pH}$ range, shows low sensitivity to temperature. It reduces sludge quantities and improves sludge dewaterability (Martí [11], Harper and Rosenberg [12], Diamadopoulos and Vlachos [13]). In this study PACl (Commercial - supplied by GRASIM, India) was used in conjunction with Alum to reduce the quantity of Alum and/or to improve the treated water quality, as well as independently as a coagulant. Based on a series of studies the following operating conditions were selected.

- Coagulation speed $150 \mathrm{rpm}$.

- Coagulation time $1 \mathrm{~min}$.

- Flocculation speed $25 \mathrm{rpm}$.

- Flocculation time $20 \mathrm{~min}$.

- Settling time $30 \mathrm{~min}$.

The analytical methods were adopted from the Standard Methods for the Examination of Water and Wastewater [9].

Table 1: $\quad$ Raw water characteristics.

\begin{tabular}{|c|c|c|c|}
\hline Parameter (Unit) & Minimum & Maximum & Mean \\
\hline $\mathrm{pH}$ & 7.740 & 8.438 & 8.151 \\
\hline Turbidity (NTU) & 30.6 & 151 & 77.6 \\
\hline $\begin{array}{c}\text { Total Dissolved Solid } \\
\text { (TDS) (ppm) }\end{array}$ & 115 & 199 & 149 \\
\hline $\begin{array}{c}\text { Total Hardness (as } \\
\mathrm{CaCO} \text { mg/L) }\end{array}$ & 90 & 160 & 118 \\
\hline $\begin{array}{c}\text { Total Alkalinity (as } \\
\mathrm{CaCO}\end{array}$ mg/L) & 101 & 184 & 135 \\
\hline Total Aluminum (mg/L) & 0.000 & 0.015 & 0.007 \\
\hline Total Iron (mg/L) & 0.377 & 0.496 & 0.437 \\
\hline
\end{tabular}




\section{Results and discussion}

\subsection{Study of coagulants}

\subsubsection{Variation of $\mathbf{p H}$ in treated water}

Figures 1 and 2 show the percentage reduction of $\mathrm{pH}$ with aluminium sulphate, potash alum and poly-aluminium chloride as coagulants. In all the three cases, percentage reduction of $\mathrm{pH}$ increases with the dosages of the coagulants. However, the values of percentage reduction are positive for aluminium sulphate and alum, whereas they are negative for $\mathrm{PACl}$. This may be due to the fact that aluminium sulphate and potash alum being acidic salt, they reduce the $\mathrm{pH}$ of the treated water, whereas $\mathrm{PACl}$ being a polymerized compound does not dissociate in the same manner in the solution.

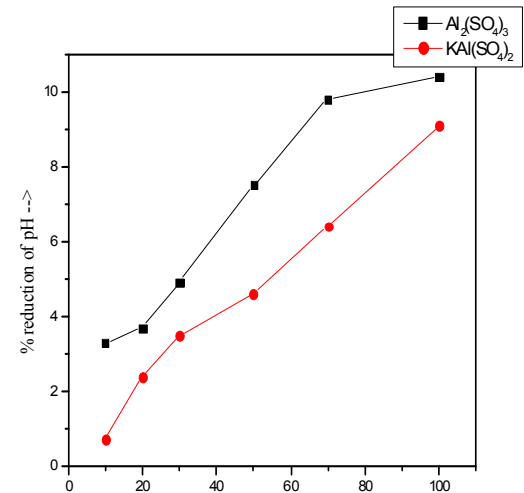

Figure 1: Dosages of $\mathrm{Al}_{2}\left(\mathrm{SO}_{4}\right)_{3}$, $\left.16 \mathrm{H}_{2} \mathrm{O}\right) / \mathrm{KAl}\left(\mathrm{SO}_{4}\right)_{2}$, $\left.12 \mathrm{H}_{2} \mathrm{O}\right) \rightarrow($ in ppm).

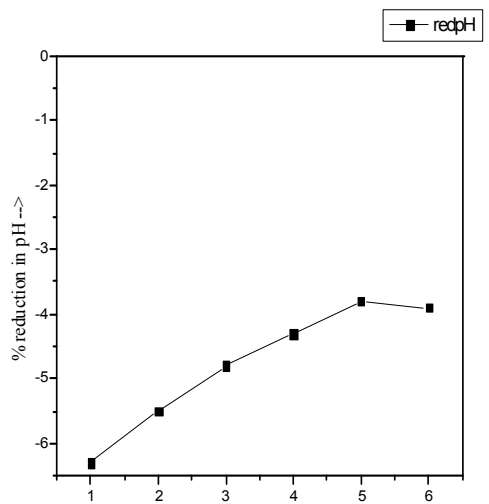

Figure 2: Dosages of $\mathrm{PACl} \rightarrow$ (in ppm).

\subsubsection{Variation of turbidity in treated water}

Figures 3 and 4 show the percentage reduction of turbidity with aluminium sulphate, potash alum and poly-aluminium chloride. In all the three cases, the percentage reduction of Turbidity increases with the dosages of the coagulants. However, for aluminium sulphate and alum the increase is rapid in lower dosages up to 20ppm and reaches a saturation level i.e. small changes occur beyond $30 \mathrm{ppm}$. In the case of $\mathrm{PACl}$ the increase is gradual for the whole study range up to $6 \mathrm{ppm}$ of $\mathrm{PACl}$.

\subsubsection{Variation of total alkalinity in treated water}

Figures 5 and 6 show the percentage reduction of total alkalinity with aluminium sulphate, potash alum and $\mathrm{PACl}$. In this case for all the three coagulants the percentage reduction value increases with the increase in coagulant dosages. However, the natures of the curves are not the same. 


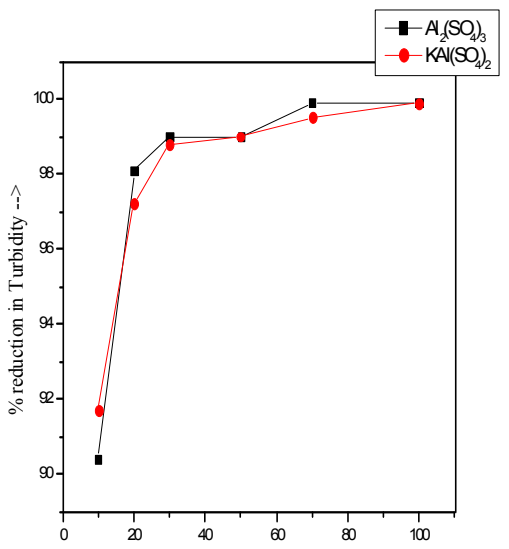

Figure 3: Dosages of $\mathrm{Al}_{2}\left(\mathrm{SO}_{4}\right)_{3}$, $\left.16 \mathrm{H}_{2} \mathrm{O}\right) / \mathrm{KAl}\left(\mathrm{SO}_{4}\right)_{2}$, $\left.12 \mathrm{H}_{2} \mathrm{O}\right) \rightarrow($ in ppm $)$.

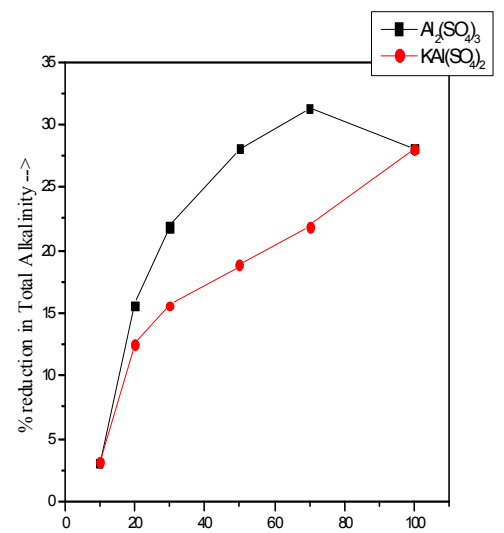

Figure 5: Dosages of $\mathrm{Al}_{2}\left(\mathrm{SO}_{4}\right)_{3}$, $\left.16 \mathrm{H}_{2} \mathrm{O}\right) / \mathrm{KAl}\left(\mathrm{SO}_{4}\right)_{2}$, $\left.12 \mathrm{H}_{2} \mathrm{O}\right) \rightarrow($ in ppm $)$.

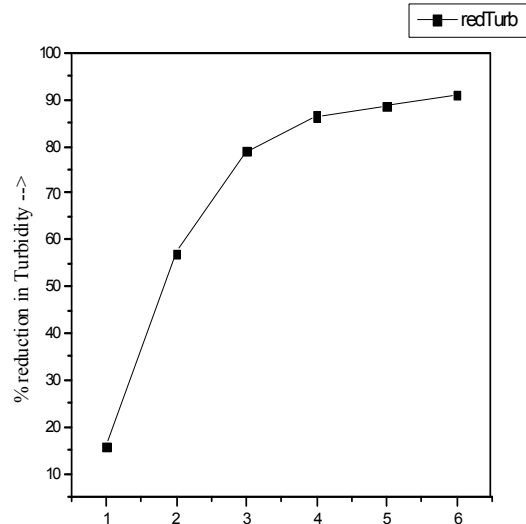

Figure 4: Dosages of $\mathrm{PACl} \rightarrow($ in ppm).

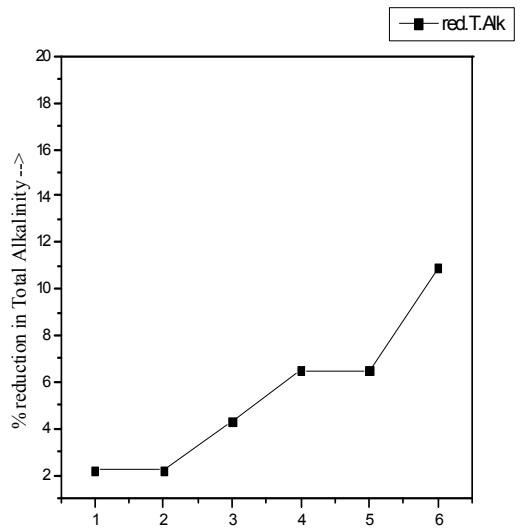

Figure 6: Dosages of $\mathrm{PACl} \rightarrow($ in ppm).

\subsubsection{Variation of sludge volume in treated water}

Figures 7 and 8 show the variation of sludge volume with aluminium sulphate, potash alum and PACl used as coagulants. For all the three coagulants the sludge volumes increase with increase of the amount of coagulants. However, the sludge volume (in $\mathrm{mL} / \mathrm{L}$ ) is considerably low in the case of $\mathrm{PACl}$ compared with aluminium sulphate or potash alum. 


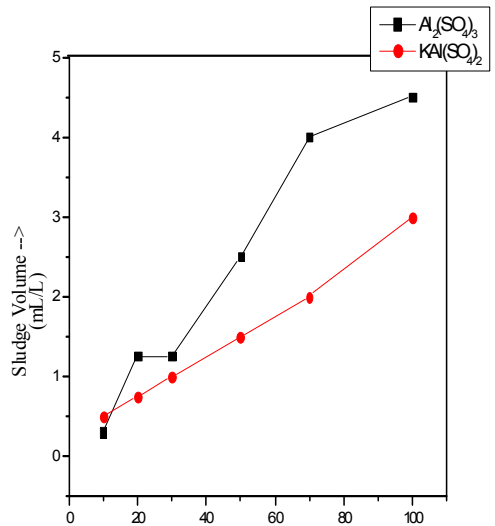

Figure 7: Dosages of $\mathrm{Al}_{2}\left(\mathrm{SO}_{4}\right)_{3}$, $\left.16 \mathrm{H}_{2} \mathrm{O}\right) / \mathrm{KAl}\left(\mathrm{SO}_{4}\right)_{2}$, $\left.12 \mathrm{H}_{2} \mathrm{O}\right) \rightarrow($ in ppm).

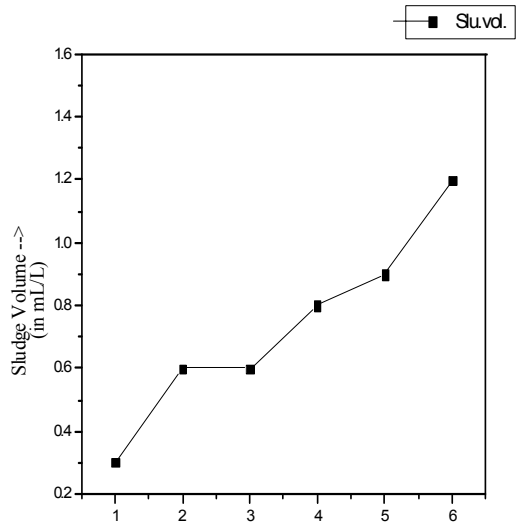

Figure 8: Dosages of $\mathrm{PACl} \rightarrow($ in ppm).

\subsubsection{Variation of residual aluminium in treated water}

From Figures 9 and 10, the amount of residual aluminium in treated water after treatment with aluminium sulphate, potash alum and $\mathrm{PACl}$ may be observed. In the case of aluminium sulphate and potash alum the residual aluminium quantities decrease with increase in the amount of coagulants, whereas for $\mathrm{PACl}$ the residual aluminium quantities increase with increase in the dosages.

This may be due to the fact that the distribution of the Al(III) species at equilibrium depends on the $\mathrm{pH}$ and the total $\mathrm{Al}$ concentration. Accordingly in the cases of aluminium sulphate and potash alum as the quantities of aluminium

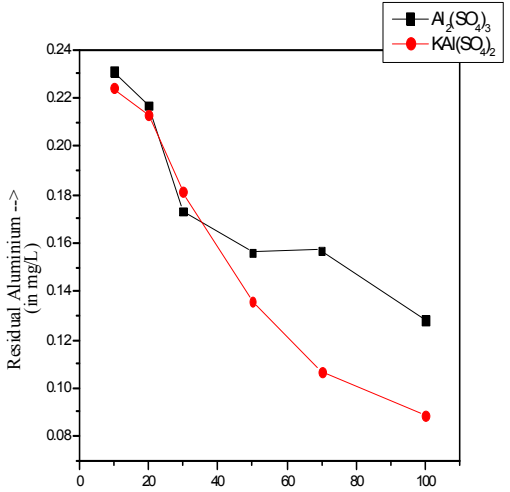

Figure 9: Dosages of $\mathrm{Al}_{2}\left(\mathrm{SO}_{4}\right)_{3}$, $\left.16 \mathrm{H}_{2} \mathrm{O}\right) / \mathrm{KAl}\left(\mathrm{SO}_{4}\right)_{2}$, $\left.12 \mathrm{H}_{2} \mathrm{O}\right) \rightarrow($ in ppm).

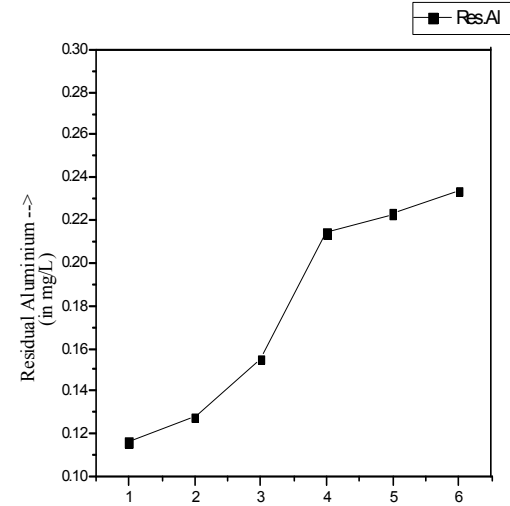

Figure 10: Dosages of $\mathrm{PACl} \rightarrow($ in ppm). 
increase the major hydrolysis product formed is $\mathrm{Al}(\mathrm{OH})_{3}$ and it readily precipitates causing sweep flocculation, reducing the quantity of available aluminium in the solution. However, in the case of $\mathrm{PACl}$, as the quantities of coagulant applied were much less compared to the other coagulants and the resulting $\mathrm{pH}$ of the solutions are higher, the soluble portions of the aluminium added increased, increasing the amount of residual aluminium.

\subsection{Study of coagulant-aids}

$\mathrm{PACl}$ and Bentonite powder were tried as coagulant aids in conjunction to potash alum.

\subsubsection{Variation of $\mathbf{p H}$ in treated water}

From Figures 11 and 12 it was observed that in case of $\mathrm{PACl}$ the percentage reduction of $\mathrm{pH}$ was negative indicating a rise in $\mathrm{pH}$ values. The magnitude of the negative $\mathrm{pH}$ values got reduced with the increase in $\mathrm{PACl}$ dosages. Whereas in the case of Bentonite Powder the percentage reduction values are positive indicating a fall in $\mathrm{pH}$ values, however, the fall did not follow a regular trend.

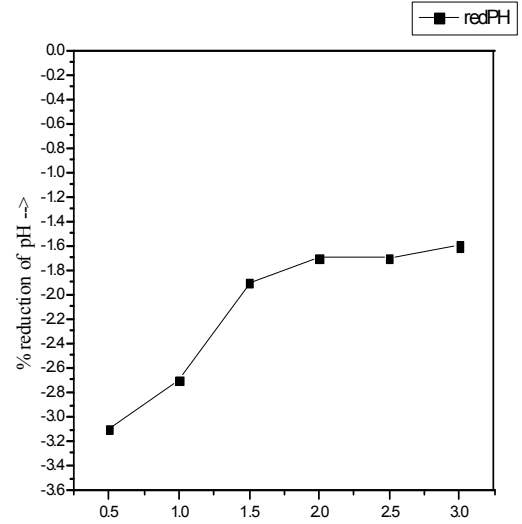

Figure 11: Dosages of PACl (in $\mathrm{ppm}) \rightarrow($ with $10 \mathrm{ppm}$ Alum each).

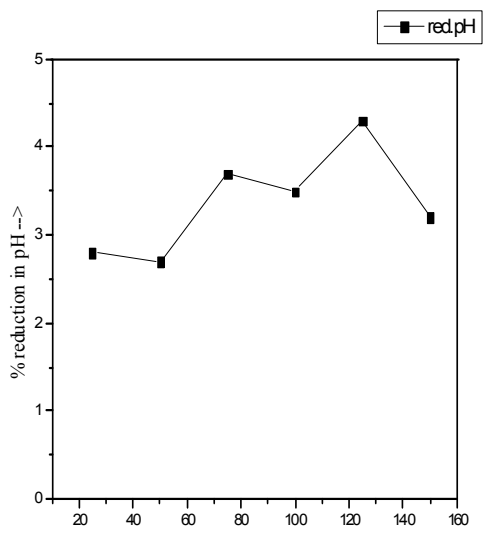

Figure 12: Dosages of Bentonite (in $\mathrm{ppm}) \rightarrow$ (with 20ppm Alum each).

\subsubsection{Variation of turbidity in treated water}

Figures 13 and 14 show the variation of turbidity with increase in dosages of coagulant aids. Figure 13 shows the percentage reduction values increased with increase in dosages of $\mathrm{PACl}$. For Bentonite powder the percentage reduction in turbidity remained static after an initial increase at the dosage of $50 \mathrm{mg} / \mathrm{L}$ Bentonite powder. This indicates inertness on the part of Bentonite Powder in turbidity removal of this river water. 


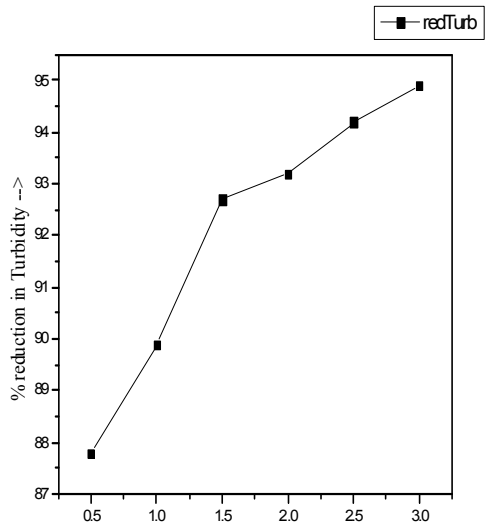

Figure 13: Dosages of PACl (in $\mathrm{ppm}) \rightarrow$ (with $10 \mathrm{ppm}$ Alum each).

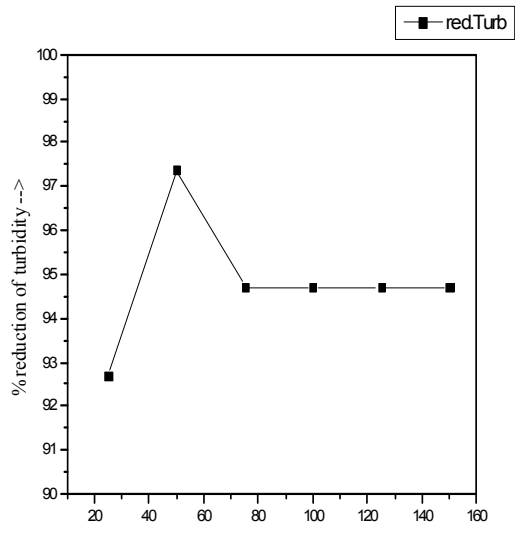

Figure 14: Dosages of Bentonite (in ppm) $\rightarrow$ (with 20ppm Alum each).

\subsubsection{Variation of total alkalinity in treated water}

Figures 15 and 16 show the variation of total alkalinity with increase in dosages of coagulant aids. For PACl the percentage reduction of total alkalinity increased with increase in dosages albeit to a very small amount. For Bentonite powder the percentage reduction was more with increase in dosages.

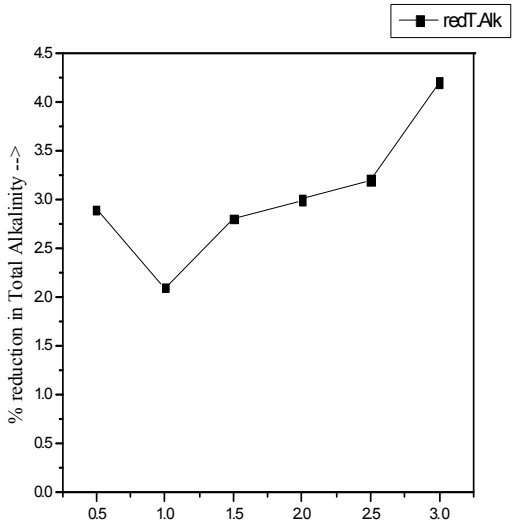

Figure 15: Dosages of PACl (in ppm) $\rightarrow$ (with 10ppm Alum each).

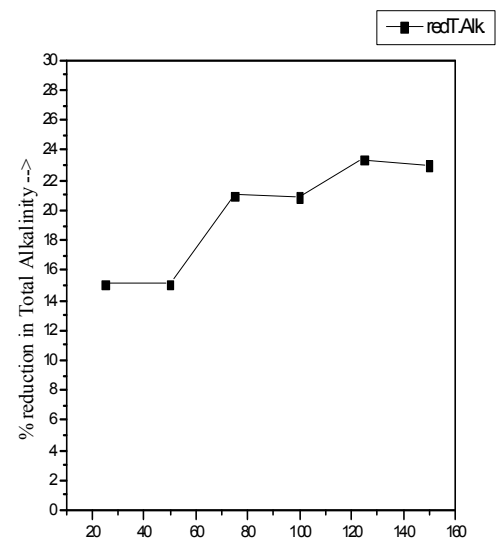

Figure 16: Dosages of Bentonite (in ppm) $\rightarrow$ (with 20ppm Alum each). 


\subsubsection{Variation of sludge volume in treated water}

Figures 17 and 18 show the variation of sludge volume with increase in dosages of coagulant aids. For both the coagulant aids sludge volumes increased with increase in dosages. However the sludge volume is considerably low in case of $\mathrm{PACl}$ compared with that of Bentonite powder.

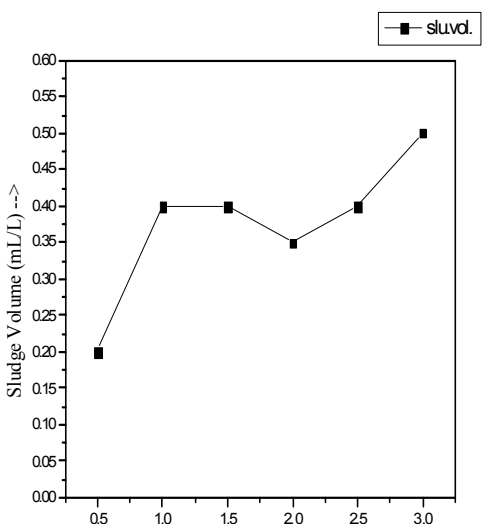

Figure 17: Dosages of PACl (in ppm) $\rightarrow$ (with 10ppm Alum each).

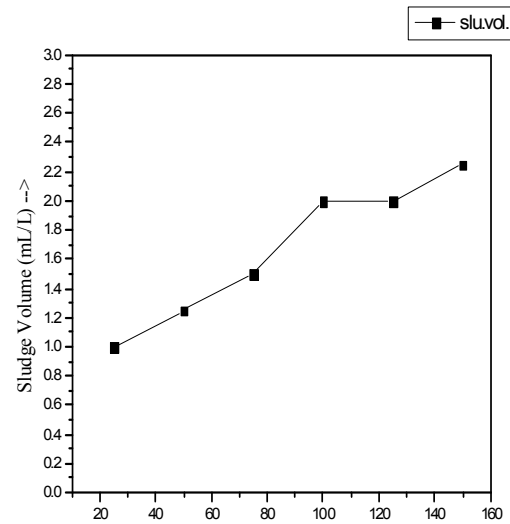

Figure 18: Dosages of Bentonite (in ppm) $\rightarrow$ (with 20ppm Alum each).

\subsubsection{Variation of residual aluminium in treated water}

Figures 19 and 20 show the variation of residual aluminium with increase in dosages of coagulant aids. For both the coagulant aids the residual aluminium

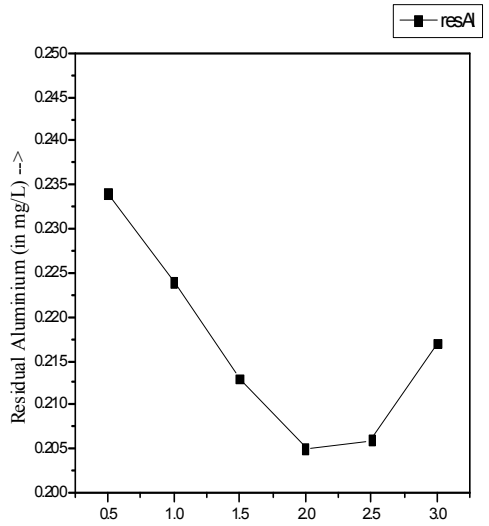

Figure 19: Dosages of $\mathrm{PACl}$ (in $\mathrm{ppm}) \rightarrow$ (with 10ppm Alum each).

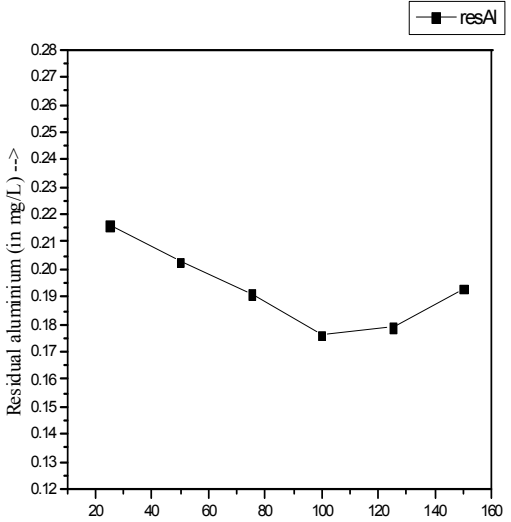

Figure 20: Dosages of Bentonite (in $\mathrm{ppm}) \rightarrow$ (with 20ppm Alum each). 
value decreased with increase in dosages initially, however the trend reversed at the end. This may be due to the fact that initially the main coagulant i.e. potash alum played the major part in turbidity removal by way of sweep flocculation, however with increase in dosages of $\mathrm{PACl}$ and Bentonite powder the soluble components of hydrolysis products increased thereby increasing the amount of residual aluminium.

\section{Conclusions}

Based on the results and discussions above it may be concluded that the hydrolyzing metal salts (HMS) in the form of $\mathrm{Al}_{2}\left(\mathrm{SO}_{4}\right)_{3}, 16 \mathrm{H}_{2} \mathrm{O}$ and potash alum reduced the $\mathrm{pH}$ value of the treated water, whereas $\mathrm{PACl}$ increased the same. This was also seen even when $\mathrm{PACl}$ was used in conjunction with potash alum. Bentonite powder however reduced the $\mathrm{pH}$ of HMS but to a lesser extent.

Regarding reduction of turbidity both the HMS exhibited good performance with the required turbidity being achieved within 20ppm. With $\mathrm{PACl}$ the required turbidity was achieved within $4 \mathrm{ppm}$. When used in conjunction with potash alum the required turbidity could be achieved with alum quantity of $10 \mathrm{ppm}$ and only $0.5 \mathrm{ppm}$ of $\mathrm{PACl}$. However Bentonite powder was not very effective in the removal of turbidity or reduction of potash alum quantity.

Total alkalinity was reduced in all the cases with increase in dosages of coagulants and/or aids.

Sludge volume was considerably reduced when $\mathrm{PACl}$ was used with potash alum compared with all the other cases.

In the cases of residual aluminium, for HMS the residual aluminium quantity reduced with the increase in coagulant quantity, however for $\mathrm{PACl}$ the quantity increased with dosages. However, as the required $\mathrm{PACl}$ quantity was small the absolute value of residual aluminium quantity was comparable to that of HMS. When PACl was used as an aid to potash alum, initially the residual aluminium decreased and then it increased at end region of the curve.

Considering all the parameters the most suitable coagulant among normally available aluminium based salts, for this type of low or medium turbidity raw water may be taken as a combination of low dosage of one HMS salt with very low quantity of PACl.

\section{References}

[1] Gregory J., Stability and flocculation of colloidal particles. Effluents Water J; 17:515-21, 1977.

[2] Franceschi, M., Girou, A., Carro-Diaz, A. M., Maurette, M. T., PuechCostes, E. Optimisation of the coagulation-flocculation process of raw water by optimal design method. Water Research 36 3561-3572, 2002.

[3] Alaert G, Van Haute A., Coagulation and flocculation mechanism in diverse colloidal suspensions. Proceedings of Joint Seminar of S.V. ward S.E.D.E., p. 45-74, 1981. 
[4] Li G, Gregory J., Flocculation and sedimentation of high turbidity waters. Water Res; 25:1137-43, 1991.

[5] Pan, R. J., Huang, C., Chen, S., Chung, Y. C. Colloids Surf., A: Physicochem. Eng. Aspects, 147, 359-364, 1999.

[6] Divakaran, R., Pillai, V. N. S. Water Res., 35, 3904-3908, 2001.

[7] Schintu, M., Meloni, P., Contu, A. Ecotoxicol. Environ. Saf., 46, 29-33, 2000.

[8] Dempsey B., Removal of naturally occurring compounds by coagulation and sedimentation. Crit Rev Environ Control; 14(4):311-31, 1984.

[9] APHA, Standard Methods for the Examination of water and Wastewater. $20^{\text {th }}$ ed. American Public Health Association, American Water Works Association, Water Environment Federation, Washington, DC, 1998.

[10] ASTM, Standard Practice for Coagulation-Flocculation Jar Test of Water E1-1994 R(1995), D 2035-80. Annual Book of ASTM Standards, Vol. 11.02, 1995.

[11] Martí, M., Policloruro de aluminio: un floculante innovador. Química 2000 18, 60-63, 1987.

[12] Harper, T., Rosenberg, A., Polyaluminium chloride: an alternative to conventional coagulants. World Water Environ. Eng. (October), 25, 1995.

[13] Diamadopoulos, E., Vlachos, C., Coagulation - filtration of a secondary effluent by means of pre-hydrolyzed coagulants. Water Sci. Technol. 33 (10-11), 193-201, 1996.

[14] André Lerch, Stefan Panglisch, Patrick Buchta, Yoshiho Tomita, Hitoshi Yonekawa, Kohji Hattori, Rolf Gimbel Direct river water treatment using coagulation/ceramic membrane microfiltration. Desalination 179, 41-50, 2005.

[15] Bolto, B.A., Dixon, D.R., Gray, S.R., Chee, H., Harbour, P.J., Ngoc, L., Ware, A., The use of soluble organic polymers in waste treatment. Water Sci. Technol. 34 (9), 117-124, 1996.

[16] Aguilar, M. I., Sáez, J., Lloréns, M., Soler, A., J.F. Ortuño, J. F., Meseguer, V. A. Fuentes Improvement of coagulation-flocculation process using anionic polyacrylamide as coagulant aid. Chemosphere, 58, 47-56, 2005. 